\title{
Interactions between wind-blown snow redistribution and melt ponds in a coupled ocean-sea ice model
}

Article

Accepted Version

Creative Commons: Attribution-Noncommercial-No Derivative Works 4.0

Lecomte, O., Fichefet, T., Flocco, D., Schroeder, D. and Vancoppenolle, M. (2015) Interactions between wind-blown snow redistribution and melt ponds in a coupled ocean-sea ice model. Ocean Modelling, 87. pp. 67-80. ISSN 1463-5003 doi: https://doi.org/10.1016/j.ocemod.2014.12.003 Available at https://centaur.reading.ac.uk/54553/

It is advisable to refer to the publisher's version if you intend to cite from the work. See Guidance on citing.

Published version at: http://dx.doi.org/10.1016/j.ocemod.2014.12.003

To link to this article DOI: http://dx.doi.org/10.1016/j.ocemod.2014.12.003

Publisher: Elsevier

All outputs in CentAUR are protected by Intellectual Property Rights law, including copyright law. Copyright and IPR is retained by the creators or other copyright holders. Terms and conditions for use of this material are defined in the End User Agreement.

www.reading.ac.uk/centaur 
Central Archive at the University of Reading

Reading's research outputs online 


\title{
Impact of wind-blown snow redistribution on melt ponds in a coupled ocean-sea ice model
}

\author{
O. Lecomte ${ }^{\mathrm{a}, *}$, T. Fichefet ${ }^{\mathrm{a}}$, D. Flocco ${ }^{\mathrm{b}}$, D. Schroeder ${ }^{\mathrm{b}}$, M. Vancoppenolle ${ }^{\mathrm{c}}$ \\ ${ }^{a}$ Georges Lemaître Center for Earth and Climate Research, Earth and Life Insitute, \\ Université Catholique de Louvain, Place Louis Pasteur 3 - Boîte L4.03.08, 1348, \\ Louvain-la-Neuve, Belgium \\ ${ }^{b}$ Department of Meteorology, University of Reading, Earley Gate, PO Box 243, Reading, \\ $R G 6$ 6BB, UK \\ ${ }^{c}$ Laboratoire d'Océanographie et du Climat (Expérimentations et Approches Numériques) \\ LOCEAN-IPSL Bô̂te 100, 4 Place Jussieu, 75252 Paris Cedex 05, France
}

\begin{abstract}
In order to study the large-scale influence of snow depth changes due to windredistribution on melt pond formation, an explicit melt pond scheme is introduced into a coupled ocean-sea ice model. For the first time, such a model includes new snow thermophysics and a wind-blown snow redistribution parameterization. The comparison of long-term mean statistics of melt pond fractions against observations demonstrates realistic melt pond cover on average over Arctic sea ice, but a clear underestimation of the pond coverage on the multiyear ice (MYI) of the western Arctic Ocean. The latter shortcoming originates from the concealing effect of persistent snow on forming ponds, impeding their growth. Analyzing a second simulation with intensified snow drift enables the identification of two distinct modes of sensitivity in the melt pond formation process. First, the larger proportion of wind-transported snow that is lost in leads directly curtails the late spring snow volume on sea ice and facilitates the early development of melt ponds on MYI. In contrast, a combination of higher air temperatures and thinner snow prior to the onset of melting sometimes make the snow cover switch to a regime where it melts entirely and rapidly. In the latter situation, seemingly more frequent on first-year ice (FYI), a smaller snow volume directly relates to a reduced melt pond cover. Notwithstanding, changes in snow and water accumulation on seasonal sea ice is naturally limited, which lessens the impacts of wind-blown snow redistribution on FYI, as compared to those on MYI. At the basin scale, the overall increased melt pond cover results in decreased ice volume via the ice-albedo feedback in summer, which is experienced almost exclusively by MYI.
\end{abstract}

Keywords: snow, sea ice, melt ponds, model 2014 MSC: 00-01, 99-00

\footnotetext{
* Corresponding author

Email address: olivier.lecomte@uclouvain.be (O. Lecomte)
} 


\section{Introduction}

Soon after the initiation of the summer surface melt on Arctic sea ice, meltwater starts accumulating in pools called melt ponds that usually cover up to $50-60 \%$ of the sea ice area during summer. The processes driving the forma-

5 tion and evolution of those melt ponds are well documented (e.g., Fetterer and Untersteiner, 1998; Perovich et al., 2002: Polashenski et al., 2012). The most important consequence of the pond formation with respect to the sea ice energy and mass balance is the critical drop in surface albedo wherever ponds form, triggering further ice surface and basal melt through the ice-albedo feedback.

10 The crucial role of melt ponds in controlling the evolution of the sea ice albedo thus make them a key component of the polar climate system.

Serious efforts have already been invested in the representation of melt ponds in large-scale sea ice models (e.g., Pedersen et al., 2009, Flocco et al., 2010, 2012, Holland et al., 2012, Hunke et al., 2013). Those studies gave evidence that mod-

15 els are sensitive to the representation of melt ponds and showed that actually accounting for their influence on the ice-albedo feedback leads to consequential sea ice volume reductions. Even so, those models are not comprehensive yet and still lack a few of the processes driving the formation and evolution of melt ponds. Among them are snow-related processes.

20 The sea ice snow cover is one of the main short and long term controlling factors for melt pond distributions, for several reasons. The first is that freshwater from snow melt on sea ice participates to feeding the ponds as they start forming. Secondly, pooling meltwater may remain hidden by a thick snow cover as long as it has not melted entirely, affecting both the timing and intensity of 25 the local albedo feedback that is triggered when ponds become visible. Lastly, the refreezing of meltwater at the base of the snow pack has been shown to create superimposed ice atop sea ice. Those locations of surficial ice formation may then turn into topographic high spots under snow dunes, between which ponds form (Freitag and Eicken, 2003: Polashenski et al., 2012; Petrich et al., 2012).

30 Snow also has a more indirect but important impact on melt pond formation through its influence on ice permeability and surface topography. Superimposed ice formation (e.g., Eicken et al., 2004) and interposed ice formation within brine channels (e.g., Polashenski et al., 2012) alter the permeability of ice and thus the way maltwater is drained through the ice. Besides, by exerting

35 control over the ice growth due to its insulating power, snow constrains the ice thermodynamic growth and thickness distribution. Melt pond formation is also very sensitive to the geometry and scale of snow depth distributions, which are extremely heterogeneous (e.g., Sturm et al. 2002), mostly due to blowing snow effects and to a frequently uneven sea ice surface topography. Depending on the

40 nature of an ice floe, whether it is multi-year or seasonal, level or deformed, the wind tends to draw manifold snow drift features at its surface, such as dunes, sastrugi or accumulation patterns under the lee of sea ice pressure ridges (Sturm 
and Massom, 2009). In light of those elements, the question of the indirect influence of blowing snow on melt pond formation through the reshaping of the snow cover becomes legitimate, and may lead to different answers for different ice types.

In the present paper, we therefore aim at (1) simulating a realistic melt pond cover on Arctic sea ice, (2) understanding the large-scale influence of snow depth changes due to wind-blown snow redistribution on melt pond formation and evo-

50 lution and (3) assess the similarity or dissimilarity of those impacts on first-year ice (FYI) and multi-year ice (MYI). Both because melt ponds are relatively uncommon and because their extensive observation is nonexistent in the Southern Ocean, our study focusses on the Arctic. So as to achieve this work, the explicit melt pond formalism of Flocco and Feltham (2007) was incorporated 55 into the Louvain-la-Neuve Sea Ice Model (LIM), which is fully coupled with the ocean general circulation model NEMO-OPA (Nucleus for European Modelling of the Ocean - Ocean PArallelisé). In particular, LIM includes a snow scheme of intermediate complexity (Lecomte et al., 2013) and a newly developed parameterization of blowing snow effects, a novelty for such kind of model. The

60 following section introduces the model, before the forcing and observations used in this study are described in sections 3 and 4 . In section 5 and 6 , we proceed to the assessment and intercomparison of two forced-atmosphere configuration simulations. The first one is a control run evaluated against observations and the second is a simulation designed to appraise the effects of enhanced snow 65 drift on snow depth, melt pond area and sea ice volume. The analyses are performed using long-term mean sea ice and snow diagnostics over the Arctic Basin. Section 7 finally summarizes the results.

\section{Model description}

\subsection{Ocean and sea ice}

70 NEMO-LIM (Nucleus for European Modeling of the Ocean - Louvain-laNeuve Sea Ice Model) is a state-of-the-art global coupled ocean-sea ice model. Its ocean component is the general circulation model OPA (Ocean PArallelisé, version 9) and is fully documented in Madec (2008). The thermodynamicdynamic sea ice model, on the other hand, is LIM3 (LIM, version 3) and is

75 coupled to the ocean component following Goosse and Fichefet (1999). This model, comprehensively described in Vancoppenolle et al. (2009), includes an explicit representation of the subgrid-scale distributions of ice thickness, enthalpy, salinity and age. Sea ice thermodynamics are computed for each sea ice thickness category following Bitz and Lipscomb (1999) and halodynamics use 80 empirical parameterizations for gravity drainage and percolation of brines. The elastic-viscous-plastic (EVP) rheology of Hunke and Dukowicz (1997) in the Cgrid formulation of Bouillon et al. (2009) is used to solve the sea ice dynamics. We run the model in the same configuration as in Lecomte et al. (2013), i.e., on the global tripolar ORCA1 grid of the ocean model (1 degree resolution), with

855 ice thickness categories (each of them being divided into 5 layers for sea ice 
halo-thermodynamics) and 42 vertical levels in the ocean. Spurious model drift in salinity is prevented by a sea surface restoring term (toward climatological values of Levitus, 1998) in the freshwater budget.

\subsection{Snow} face melt or sublimation based on the imbalance of the surface heat budget and a representation of snow ice formation based on Fichefet and Morales Maqueda (1997).

100 Two important additions were made to the snow thermodynamics as compared to Lecomte et al. (2013). They are related to the inclusion of melt ponds in the model. The first is the treatment of the physical impacts of liquid water presence in snow and the second is the albedo calculation (see section 2.3.2). Indeed, new model variables related to the water storage were required to cou105 ple NEMO-LIM to an explicit melt pond scheme (see section 2.3). Benefit was taken from these new variables to account for wet snow properties and superimposed ice formation into the snow. Because snow gets saturated with water very quickly (Jordan et al. 2008, Sturm and Massom, 2009), we assume that the snow cover is wet whenever the liquid water reservoir is not empty (for a given 110 ice category, in a single grid cell). As in Hunke et al. (2013), water infiltration in the snow is computed based on the amount of water available and the volumes being possibly occupied in snow, depending on its density. The mass fraction of liquid water relative to the total mass of water and snow in a layer is then used to alter the snow thermal conductivity, calculated as a weighted mean of snow 115 and freshwater thermal conductivities. Finally, freshwater that may refreeze in case of divergence of the conductive heat fluxes going in and out of a saturated snow layer is given by:

$$
-L_{f} \frac{d m_{r f w}}{d t}=f c_{s}^{i n}-f c_{s}^{o u t}
$$

where $L_{f}$ is the latent heat of fusion, $m_{r f w}$ the mass of refrozen freshwater, and $f c_{s}^{\text {in }}$ and $f c_{s}^{\text {out }}$ the conductive heat fluxes at the interfaces of the snow layer, respectively. The adopted formalism is similar to Cheng et al. (2006), except that the refrozen water does not become part of the sea ice mass underneath. Instead, it is incorporated to the mass of snow, affecting its density and slackening the early stages of the snow melt. This process acts as a sink for the melt pond water, as long as snow remains present and water volumes are small. Note 125 that, on the contrary, in case of convergent conductive heat fluxes in a snow layer at the melting point, snow melts internally and becomes a source for the freshwater reservoir. 


\subsubsection{Blowing snow}

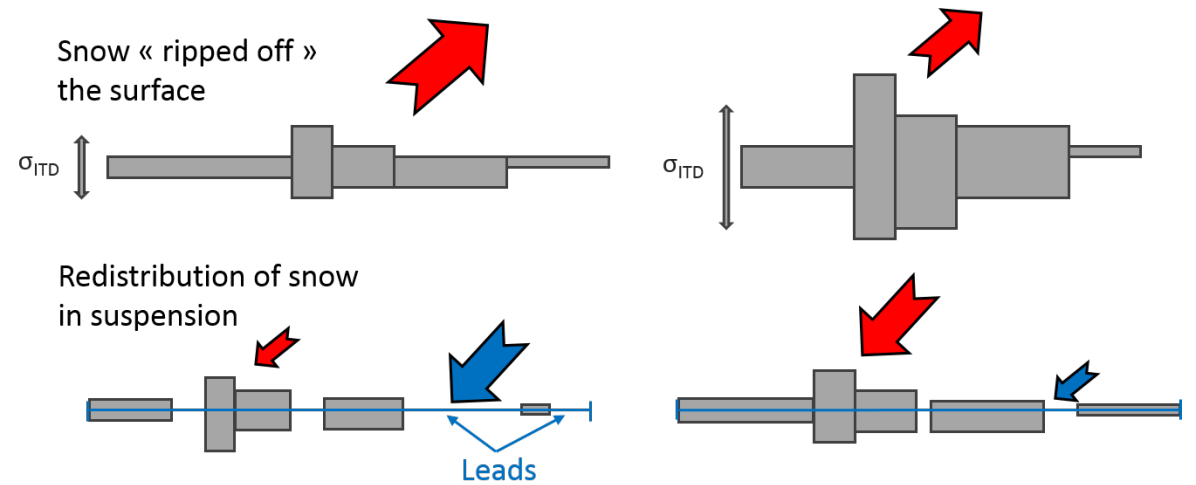

Figure 1: Schematic representation of the snow redistribution by winds on the subgrid-scale distribution of ice thicknesses in the model. Grey boxes represent the ice thickness categories. The height and width of each box symbolizes the thickness and area coverage of each category. $\sigma_{I T D}$ stands for the standard deviation of the ice thicknesses (from categories) within a grid cell. For instance, using five ice categories in the model provides five ice thickness values per grid cell. $\sigma_{I T D}$ is the standard deviation over those five values. Top plots show how $\sigma_{I T D}$ influences the snow mass fluxes (upward red arrows) from the ice during blowing snow transport. Basically, flat ice (translating in small $\sigma_{I T D}$ ) enables stronger erosion rates, hence larger mass fluxes of snow removed from the ice when snow drift is triggered, and conversely for deformed ice. Bottom plots show how the wind-transported snow mass is partitioned between mass fluxes to the ice (downward red arrows) and a mass flux to the ocean through the cracks between the ice floes (blue arrows) during redeposition (see section 2.2.2). The fraction of the total transported snow mass that is lost in leads is proportional to the area of open water in the grid cell.

Blowing snow (or snow drift) on sea ice tends to redistribute the snow mass from thin level ice to thicker and deformed ice. The process smoothes out small and high frequency changes in sea ice topography while enhancing larger topographic features such as pressure ridges (Sturm et al., 2002). Usually, the "blowing snow"term includes several sub-processes such as snow erosion and motion by saltation or suspension (snow transport by winds). Snow drift is also a sublimation-enhancing process, facilitating the sublimation of grains thrown in suspension (Déry and Yau, 2002). The impacts of such mechanisms are well documented (e.g., Déry and Tremblay, 2004, King et al., 2008, Sturm and Massom, 2009, Leonard and Maksym, 2011). Most importantly, snow that is ripped off the pack and transported by winds may be lost into leads, or redeposited on the ice, altering the spatial distribution of snow depths. As the wind direction shifts or the floe rotates, snow undergoes further erosion that may affect the surface drag coefficient and the dynamic response of sea ice to the wind forcing. Given the difficulty of establishing a new parameterization due to the lack of observations available for this specific process, we only thought 145 to represent the zero order impact of blowing snow on the subgrid-scale snow depth distribution. To our knowledge, it is the first time such developments are 
made in a large-scale coupled ocean-sea ice model.

The usual conservation equation for a global state variable such as the total snow mass per unit area $m_{s}$ on a single ice thickness category is:

$$
\frac{\partial m_{s}}{\partial t}=-\nabla\left(m_{s} \mathbf{u}\right)+\Psi^{m_{s}}+\Theta^{m_{s}}+\Phi
$$

150

where $-\nabla\left(m_{s} \mathbf{u}\right)$ represents the horizontal advection of snow due to sea ice motion, $\Psi^{m_{s}}$ the effects of the mechanical redistribution of sea ice on snow, $\Theta^{m_{s}}$ the changes in snow mass due to the thermodynamic processes described in the previous two sections and $\Phi$ the wind-redistribution of snow. The later term may be written as:

$$
\Phi=\Phi_{\text {local }}+\Phi_{\text {nonlocal }}
$$

the local term accounting for redistribution of the snow mass over the sea ice thickness categories, and the non local one representing the snow transport from grid cell to grid cell. For the sake of simplification, we assume that, at the synoptic scale of a storm, the snow mass being transported out of a grid cell matches the amount of snow that is transported in and we therefore neglect the non local effect of blowing snow. The validity of this assumption may depend on the horizontal resolution of the model grid, but would require the coupling with an atmospheric circulation model in order to be properly tested. $\Phi_{\text {local }}$ may be separated into two terms:

$$
\Phi_{\text {local }}=\Phi_{\text {local }}^{T}+\Phi_{\text {local }}^{R}
$$

where $\Phi_{l o c a l}^{T}$ and $\Phi_{\text {local }}^{R}$ are the ripping out and re-deposition rates, respectively. Based on the thought, that snow drift mainly depends on wind speed, snow surface properties and sea ice surface topography (e.g., Sturm and Massom, 2009), we formulate those rates in a simple way, as illustrated by Figure 1 . We assume that the mass flux of snow removed from the pack and transported by winds is (1) negatively proportional to the snow density (packed snow is less erodable than light snow), (2) proportional to the wind speed, as long as it is greater than a threshold velocity $V^{\star}$ and (3) inversely proportional to the standard deviation of the ice thickness distribution $\sigma_{I T D}$ (i.e., over the thickness categories) in a grid cell. $V^{\star}$ is computed as:

$$
V^{\star}=\frac{\rho_{s}-\beta}{\alpha}
$$

where $\rho_{s}$ is the snow density and $\alpha$ and $\beta$ are coefficients that were retrieved 175 from a linear regression of observations relating the seasonal mean wind speed to the actual snow density $\left(\alpha=44.6 \mathrm{~kg} \mathrm{~m}^{-4} \mathrm{~s}\right.$ and $\beta=174 \mathrm{~kg} \mathrm{~m}^{-3}$, Lecomte et al., 2013). Physically, $V^{\star}$ represents the seasonal mean wind velocity that is required to make the snow pack as dense as $\rho_{s}$, and it is assumed that blowing snow will start only as soon as the instantaneous wind speed exceeds this value. $\sigma_{I T D}$ on the other hand is considered as a roughness length limiting 
the snow drift in case of large disparities in ice thicknesses (represented by a large $\left.\sigma_{I T D}\right)$. Given the relatively poor ice deformation diagnostics in current sea ice models, we chose this simple solution instead. However, no observation clearly support this approximation, so using the ice thickness distribution to derive surface roughness is only a temporary solution. The issue will need to be better addressed as soon as reliable sea ice topography tracers are available in such models. Some promising rhoelogy formalisms, adequate to this purpose, may become operational in sea ice models in a near term future (e.g., Girard et al. 2011). A constant mass flux coefficient $\gamma$ is used to tune the relationship 190 between $\Phi_{\text {local }}^{T}$ and the wind speed. For a same wind velocity, a higher $\gamma$ induces a larger snow mass removed from the ice (and potential losses into leads), and conversely. Since the fine calibration of this parameter based on extensive observations is currently impossible, it was adjusted to provide comparable snow volumes as those in the reeference run of Lecomte et al. (2013) and to produce mass fluxes that are physically plausible $\left(\sim 1-10 \mathrm{~g} \mathrm{~m}^{-2} \mathrm{~s}^{-1}\right.$, compared to Sugiura et al. 1998). Its standard value of $10^{-5} \mathrm{~kg} \mathrm{~m}^{-2}$. In our results below, we assess the sensitivity of our model to this new parameterization and its influence on melt pond distributions.

A fraction of the total mass of snow transported by winds, proportional to redistributed an the rest relative coverage of ice thickness categories via $\Phi_{\text {local }}^{R}$, proportionally to their sumption that wind-blown snow redistribution on sea ice is largely dependent on the size of open water areas between ice floes (Leonard and Maksym, 2011). However, the actual geometrical distribution of cracks in the ice is likely as much important as the total area of open water for snow losses into the ocean. Parameterizing the shape and size of leads or increasing the resolution to explicitely resolve them would likely influence the redistribution scheme behavior. Adressing this problem is a long term perspective for the improvement of the sea ice model and snow redistribution scheme used here.

\subsection{Melt ponds}

\subsubsection{The model}

The melt pond formulation we use is the one of Flocco and Feltham (2007) and the way it was incorporated into our sea ice model is very similar to the 215 works of Flocco et al. (2010, 2012). The real topography of sea ice is not represented in LIM3, but from the ice thickness distribution formalism the melt pond model retrieves a discretized distribution of ice surface height and basal depth with respect to an unspecified reference position. Assuming the ice in the whole grid cell is rigid and in mean hydrostatic equilibrium, the sea level 220 position is calculated with respect to those height and depth distributions. That way, the thinnest ice category may be completely below the sea level. Then, calculating the changes in water volume retained on the ice due to the manifold source and sink processes described hereafter, the depth and fractional coverage of melt ponds on the ice can be computed by distributing the water among ice 

snow cover.

In order to couple the sea ice and melt pond models, three new tracers were added: the melt pond volume, area and ice lid volume in case ponds refreeze (all three tracers are expressed per unit area of ice). For the sake of clarity,

230 Figure 2 summarizes the fresh water balance leading to the calculation of melt pond tracers during a model time step. Melt pond volume is initially fed by snow/sea ice surface melt, snow internal melt and rain. The meltwater volume in the model may then be reduced by physical infiltration and refreezing of water into the snow, as presented in section 2.2.1. At each time step, a fraction

235 of this volume (depending on the total ice concentration, Holland et al., 2012) is lost by lateral run-off through cracks or ice floe edges. If the pond surface is above the sea level, the vertical drainage of meltwater through permeable sea ice into the ocean is computed following Darcy's Law, as a function of the pressure head relative to the sea level and the ice permeability. Sea ice permeability is computed as proposed by Golden et al. (2007):

$$
\Pi=3\left(1-\phi^{3}\right) \times 10^{-8}
$$

where $\phi$ is the solid fraction within the ice, calculated as in Feltham et al. $(2006)$ :

$$
\phi=\frac{c_{b u l k}-C(T)}{C_{i}-C(T)} .
$$

$c_{\text {bulk }}$ is the bulk salinity of the ice, $\mathrm{C}(\mathrm{T})$ is salt concentration in the brine and $\mathrm{C}_{i}$ the salt concentration in the ice crystals (set to zero here). The least permeable layer within the ice determines the vertical drainage rate. When the surface heat 245 budget gets negative, melt ponds start refreezing and the growth rate of the ice lid forming on top of the melt pond is calculated using Stefan's law. The ice lid may undergo further growth or melt depending on the surface heat balance. The pond volume is also affected by sea ice advection and deformation. Fractions for melt pond and ice lid volume lost during sea ice ridging or rafting were added to the model. A few test cases showed that changing those parameters induced allmost no change in pond coverage in the model. At this stage, it is not clear whether this weak sensitivity was to be expected. We therefore prescribed the value of those fractions to $50 \%$, as it was already the case for snow in LIM3. As in Flocco et al. (2012), the fraction of ice covered by ponds in 255 each category is limited by a prescribed value that is function of its thickness: $a_{p} \max =83.2 \%-h_{i} * 2.4 \%$. Once the melt pond area fraction, depth and ice lid thickness are calculated, they are used to retrieve the effective albedo of the pond covered ice.

\subsubsection{Albedo}

260

In order to account for melt pond tracers in the albedo calculations, the melt pond albedo is first computed as a function of its depth, as in Lecomte et al. 


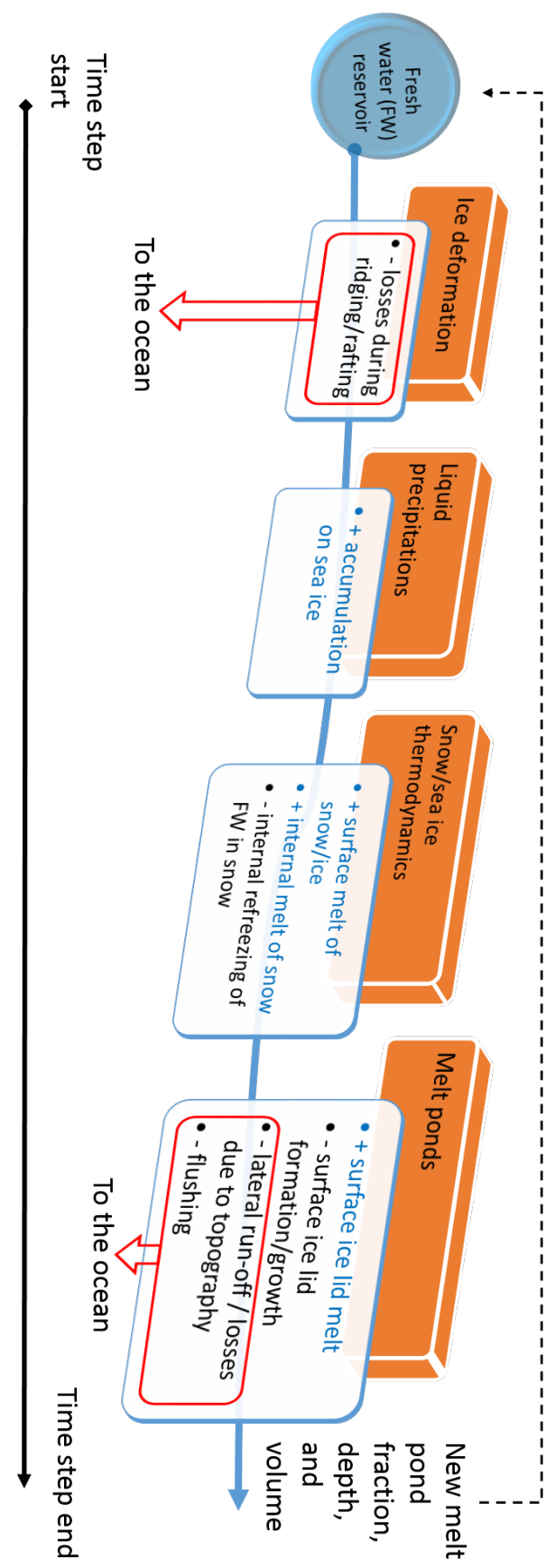

Figure 2: Evolution of the fresh water reservoir in a grid cell during a model time step. At the time step start, this reservoir is equal to the melt pond volume. All source and sink processes listed in this diagram are described in section 2.3 
(2011):

$$
\alpha_{p}= \begin{cases}\alpha_{w}-\left(\alpha_{w}-\alpha_{i}\right) e^{\frac{-h_{p}}{\omega}} & \text { if no active ice lid and active melt pond } \\ \alpha_{b i} & \text { if active ice lid }\end{cases}
$$

where $\alpha_{i}$ and $\alpha_{w}=0.30$ are the snow-covered ice and deep pond albedo, $h_{p}$ is the pond depth in $\mathrm{m}$ and $\omega$ is a constant scale factor in the same units as $h_{p}$. $\alpha_{i}$ is computed as a function of the surface wetness (melting conditions), cloud cover, snow depth and ice thickness (Shine and Henderson-Sellers, 1985), as in the former version of the model without melt ponds. $\alpha_{b i}$ is the albedo of bare ice, equal to 0.58. Note that, like in Flocco et al. (2012), melt ponds/ice lids are optically active and affect the sea ice albedo only when they are deeper/thicker than a critical value of $1 \mathrm{~cm}$. Then, the mean albedo of the various surface types weighed by their relative coverage of the ice cover is calculated:

$$
\alpha=\alpha_{i}\left(1-a_{p}\right)+\alpha_{p} a_{p}
$$

where $a_{p}$ is the melt pond fraction of ice area.

\section{Forcing and setup}

Except for precipitation, the model is driven by the same forcing fields as in Lecomte et al. (2013), all spatially interpolated onto the ORCA1 grid. NCEP / NCAR daily reanalyses of $2 \mathrm{~m}$ air temperature and $10 \mathrm{~m} u$ - and $v$ - wind components of Kalnay et al. (1996) are used, together with monthly climatologies of total cloudiness and relative humidity of Berliand and Strokina (1980) and Trenberth et al. (1989), respectively. River runoff rates are taken from Dai and Trenberth (2002). Usually, we use the climatology of Large and Yeager (2004) as precipitation input to our model. Here, in order to get a more realistic regional variability of the snowfall, we added the precipitation anomalies from DFS5.2 (DRAKKAR Forcing Set, version 5, Dussin and Barnier, 2013) to the climatology. The making of DFS5 follows the same method as in Brodeau et al. (Simmons et al., 2007 Dee et al., 2011). The reason why the full DRAKKAR precipitation forcing set was not used was to avoid introducing a large bias in model results due to a bias in the mean precipitation rates (as compared to the former climatology), which would have required further tuning of the model. Surface heat fluxes (radiative and turbulent) are derived from Goosse (1997), and the wind stress over sea ice is calculated with a quadratic bulk formula and a drag coefficient $C_{a}=1.40 \times 10^{-3}$.

Since the DFS5 precipitation data we use are available from 1979, model simulations are performed from 1979 to 2011. In sections 5 and 6, the first 295 three years of the simulations are not considered in order to let a short model spin-up before we start the analysis. The initial state for all sea ice covered regions of the Arctic Basin (defined by the locations where the sea surface temperature is below $0^{\circ} \mathrm{C}$ ) is set to $3.5 \mathrm{~m}(0.3 \mathrm{~m})$ for ice (snow) thickness, 
0.95 for ice concentration, $270 \mathrm{~K}$ for snow and ice temperatures and 6 PSU for sea ice salinity. The snow scheme is used with 3 layers advected horizontally, but the vertical resolution is refined to 6 layers in the thermodynamics. Ocean temperatures and salinities are initialized from Levitus (1998) climatological values. The ocean model runs hourly and calls to the sea ice model are made every 6 time steps.

\subsection{Results}

Here, we first analyse a control run (hereafter referred to as CTL) performed through 1982-2011, using the model as described in the previous sections. We compare CTL against the set of observations mentioned above to appraise the 330 model skills in simulating the sea ice extent, volume, snow and melt pond cover.

\subsubsection{Sea Ice}

Figure 3 shows the simulated and observed mean seasonal cycle of sea ice extent through 1982-2011, and the simulated mean cycle of sea ice volume over the same period for CTL. Sea ice extents produced by the model is in good agreement with the observed ones, except for the summer minimum, which is underestimated by half a million square kilometers and shifted from September to August. Although sea ice extent seems to be well reproduced in the simulation, sea ice volume appears too low, with a maximum and a minimum of 
$20.8 \times 10^{3} \mathrm{~km}^{3}$ and $9.7 \times 10^{3} \mathrm{~km}^{3}$, respectively. Comparing, for instance, these values with PIOMAS estimates (Zhang and Rothrock, 2003) would lead to a mean underestimation of the sea ice volume of about $20 \%$. In comparison to the reference simulation of Lecomte et al. (2013), without the new processes (i.e., melt pond representation and blowing snow), the Arctic mean sea ice extent is similar, but the volume is reduced by about $40 \%$ in winter and $50 \%$ in 345 summer (reasons are discussed in section 5.2).

The simulated ice thickness distributions (ITDs) (Figure 4) consistently show an underestimation of IceBridge ice thicknesses (Kurtz et al. 2012, updated 2013), mainly including MYI data. In March, the coverage of ice in the first three categories of ice thickness in the model is overestimated by up to $15 \%$ (for category 2 and 3), while the amount of ice in the last two categories is largely underestimated. In particular, all the ice thicker than $4 \mathrm{~m}$ observed during IceBridge flights is missing in the simulation. In April, the IceBridge ITD indicates that ice thinner than $2 \mathrm{~m}$ has kept forming since March and the relative coverage of $0-2.3 \mathrm{~m}$ thick ice has increased to the cost of 2.3-5.5 m thick 355 ice. Consequently, the biases between CTL and IceBridge ITDs are reduced, but the simulated sea ice thicknesses remain thinner than the observed ones in general, with an underestimation of 2.3-3.8 m thick ice of $\sim 13 \%$ and $4-5.5 \mathrm{~m}$ thick ice that is still completely missing.

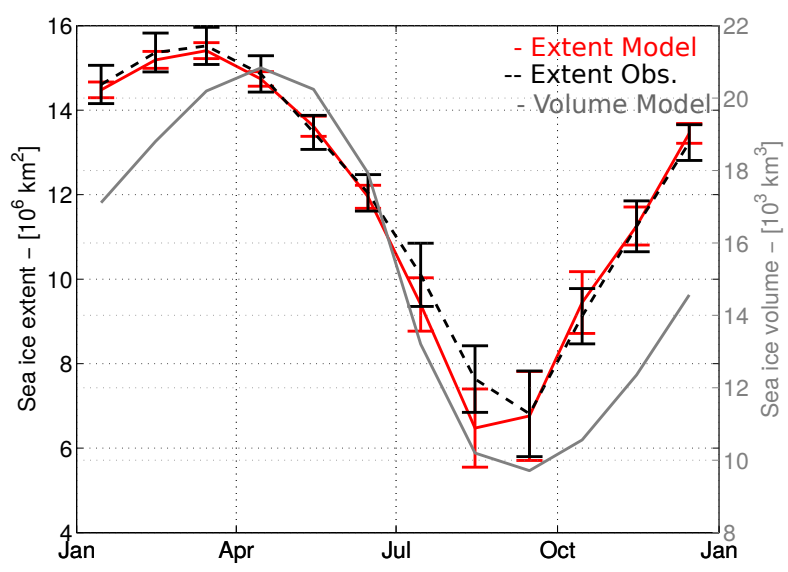

Figure 3: Simulated (red) and observed (NASA data, Comiso and Nishio 2008, dashed black) mean annual cycles of Arctic sea ice extent over 1982-2011 and simulated mean annual cycle of Arctic sea ice volume (grey) over the same period. Error bars represent the standard deviation of the monthly extents, over the simulation period.

\subsubsection{Snow}

360

Like in Lecomte et al. (2013), snow depths are relatively well simulated by the model overall, as suggested by Figure 5 which shows the snow depth distributions (SDD) in CTL versus IceBridge data. As for ice thickness, the 

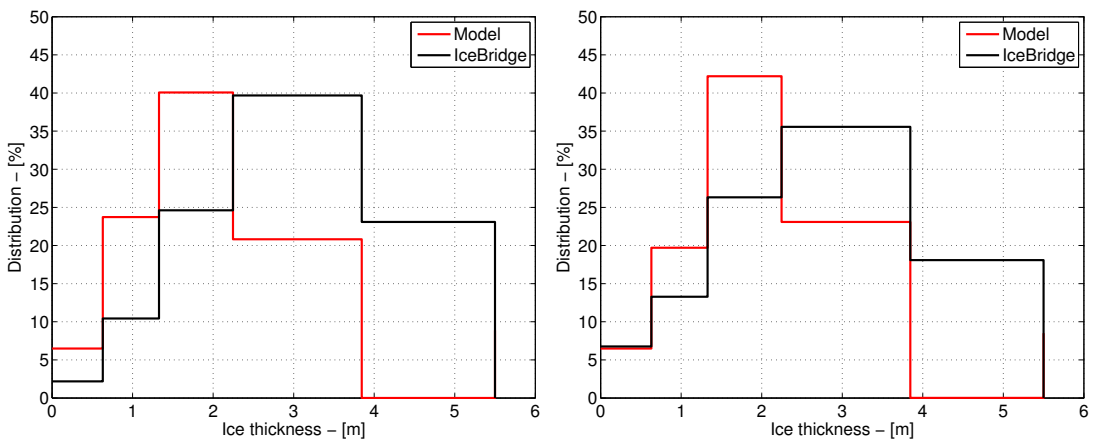

Figure 4: Ice thickness distributions (ITDs) as simulated by the model (red) and observed during IceBridge flights (Kurtz et al. 2012, updated 2013) (black), in March (left panel) and April (right panel). Simulated ITDs are averaged over the analysis period (1982-2011). Bounds in sea ice thickness correspond to those from the ice thickness distribution in the model.

simulation exhibits a bias towards thinner snow, with a large proportion of 0-5 cm deep snow (12\% in March, $9 \%$ in April, against 3\% and $5 \%$ for IceBridge, respectively) and an underestimation of $30-45 \mathrm{~cm}$ deep snow by $\sim 3 \%$. Note that the simulation features a second mode in snow depth around 45-60 cm deep snow, which is not apparent in the observations.
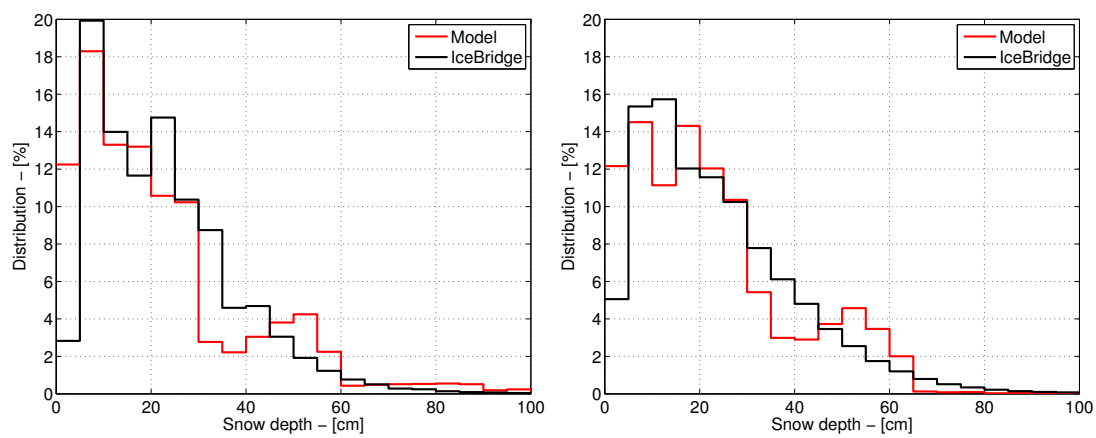

Figure 5: Snow depth distributions (SDDs) as simulated by the model (red) and observed during IceBridge flights (Kurtz et al. 2012, updated 2013) (black), in March (left panel) and April (right panel). Simulated SDDs are averaged over the analysis period (1982-2011).

\subsubsection{Melt ponds}

Figure 6 depicts the mean summer cycles of the main melt pond diagnostics

in the model, namely the area fraction of ice covered in ponds, melt pond depth, ice lid thickness (refreezing atop the pond) and the surface broadband albedo of pond covered ice. Melt ponds start forming in May, and reach their maximum coverage of 0.15 for exposed-ponds (i.e., still uncovered by a refreezing ice lid) and 0.28 for all-ponds in mid-July. The maximum depth of melt ponds 
$375(\sim 0.25 \mathrm{~m})$ is reached a month later, in August, before ponds shrink rapidly in September due to surface refreezing. The albedo consistently follows the evolution of the sea ice surface state, dropping from $\sim 0.8$ to $\sim 0.3$ in mid-August as melt ponds develop and rising again as soon as their refreezing stage begins. Specifically looking at the agreement between simulated exposed-ponds and

380 MODIS observations of melt ponds (ICDC MODIS; Rösel et al., 2012) yields a good timing of the melt pond development in the model, and a consistent maximum value for the mean melt pond fraction over the Arctic Basin (Figure 7), although it is underestimated in early season. As stated in Rösel et al. (2012), MODIS melt pond fractions are overestimated in late season since their

385 algorithm misclassifies areas of thin ice as ponded ice. Therefore, our simulated melt pond fractions may be realistic during this period. The generally low pond fraction in the Central Arctic Ocean is emphasized by Figures 8 and 9, which display the mean geographical distributions of melt pond fraction, depth and difference between CTL and MODIS satellite melt pond fractions through JuneSeptember for 2000-2011 (period with available observations). The MODIS maximum melt pond concentrations are below those obeserved on the field (e.g., Polashenski et al. 2012) and are especially not in agreement with observations in early and late season (see corresponding discussion section). This product is therefore far from absolute but provide a baseline for the model evaluation at

395 the basin scale. The maximum melt pond fractions $(\sim 0.4)$ are found in July in the Canadian Archipelago and in the transitional region between the Laptev Sea and the Arctic Ocean, whereas very deep melt ponds $(0.5 \mathrm{~m})$ are found in the Canadian Archipelago only. Overall, melt ponds tend to remain shallow in the marginal sea ice zone of the eastern basin (with fractional coverages of up to 0.35 ), while they get deeper (up to $\sim 0.35 \mathrm{~m}$ ) on the MYI of the western and central basin. These opposite patterns are particularly noticeable in July, and to a lesser extent in August. Figure 9 shows a general model tendency to underestimate the melt pond relative coverage, especially in the central basin, while some coastal regions are significantly over-covered (overestimation by 0.15 $405 \quad 0.25$ in July).

\subsection{Discussion}

The sea ice volume loss observed in CTL compared to a no-melt pond run such as in Lecomte et al. (2013) is huge (up to $50 \%$ volume loss in summer, not shown) but consistent with Flocco et al. (2012) (using the same melt pond scheme in a similar multi-category sea ice model), in which they noticed a $\sim 40 \%$ volume loss between pond and no-pond configurations. The early occurrence of the minimum ice extent on the other hand is not realistic with regard to presentday observations, but typical of a low ice volume simulation (Lecomte et al., 2013), where the ice has a weaker thermodynamical inertia and melts faster in

415 summer. In addition, in the simulation, the minimum ice extent consistently occurs at the time of the maximum unfrozen melt pond volume.

The slight underestimation of snow depths compared to IceBridge observations is primarily explained by the underestimation of the ice thickness itself, suggesting younger ice overall that is not formed yet in the early accumulation 


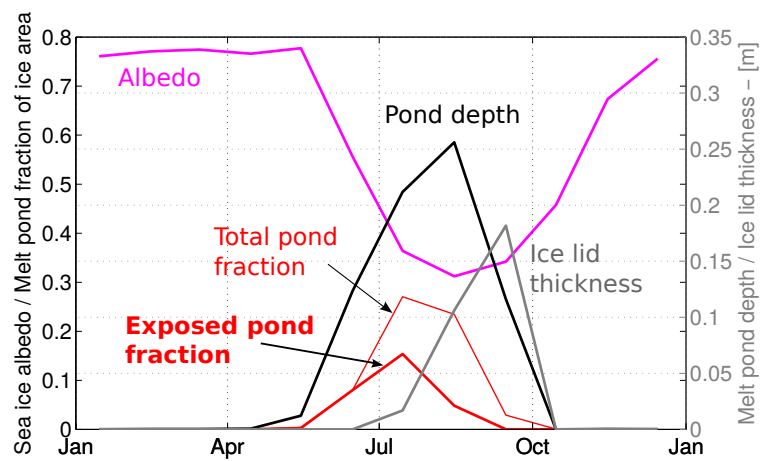

Figure 6: Mean annual cycles of melt pond-related diagnostics (through 1982-2011). The purple curve represent the ponded-ice clear sky broadband albedo. The bold and light red curves depict the exposed (not covered by an ice lid) and total melt pond fraction of ice area, respectively. Black and grey curves read on the right hand y-axis, and picture the pond depth and ice lid thickness, respectively.

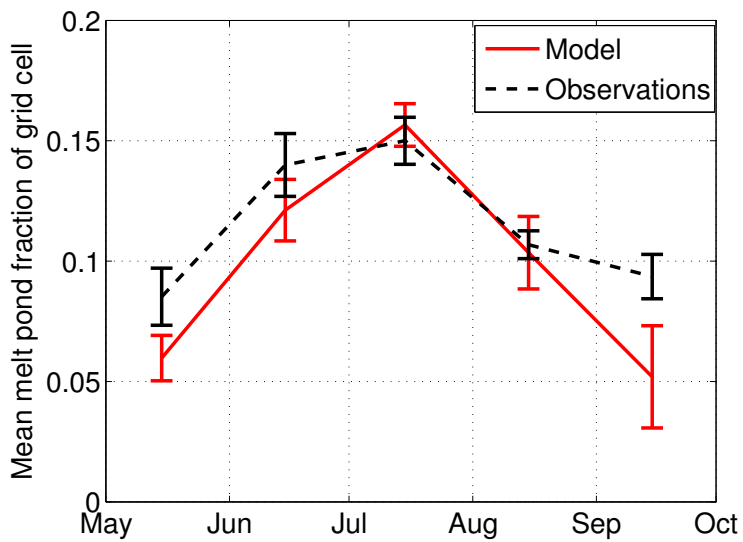

Figure 7: Mean seasonal cycles of melt pond fraction (over 2000-2011), expressed as a fraction of grid cell, from the model (red) and from MODIS observations (Rösel et al. 2012, dashed black). Error bars represent the standard deviation of the monthly melt pond fractions over $2000-2011$. 

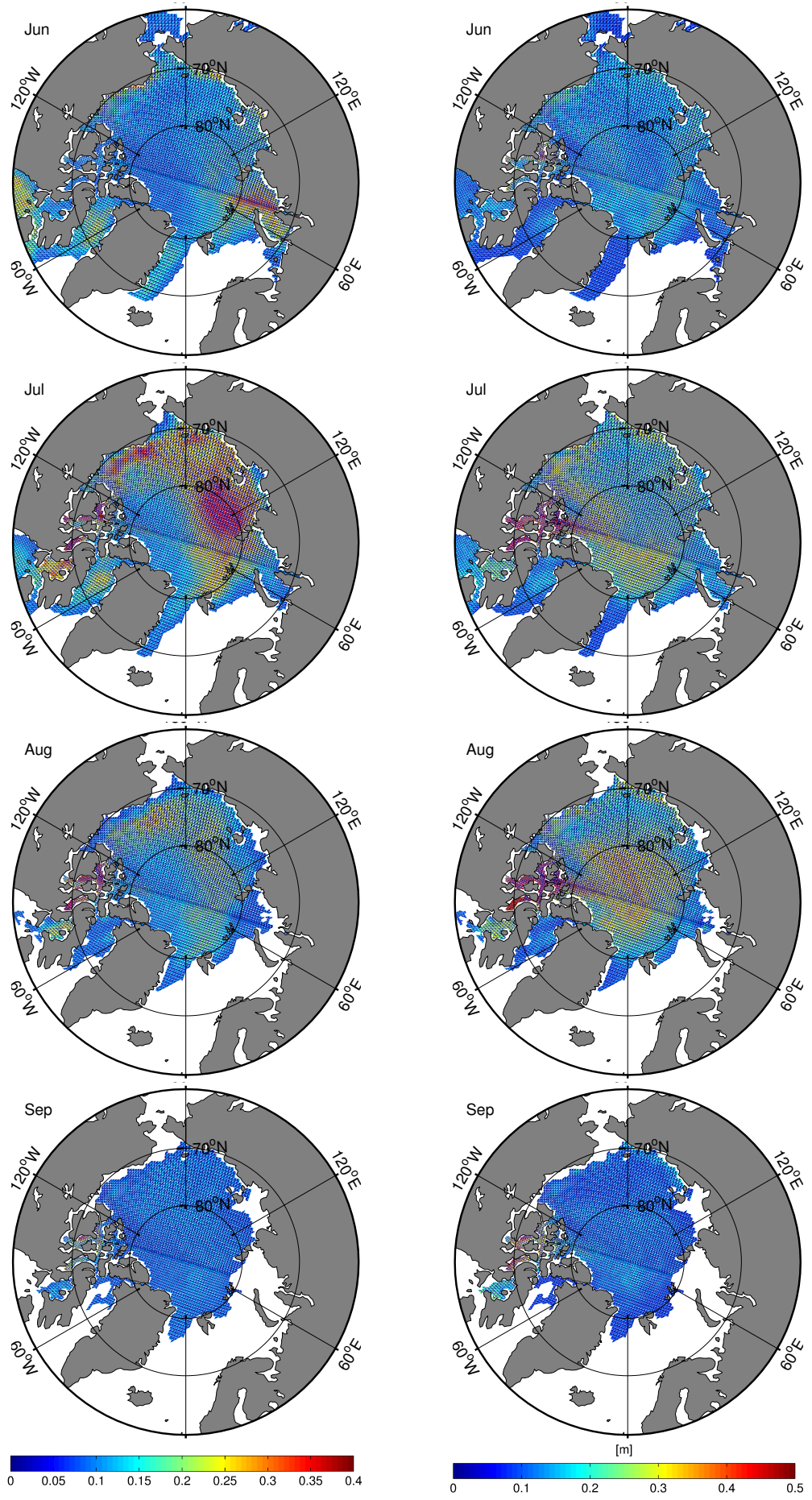

Figure 8: Average spatial distributions of melt pond fraction of ice (left) and depth (right, in meters) through June-September (downwards) over Arctic sea ice, for the 1982-2011 period. 

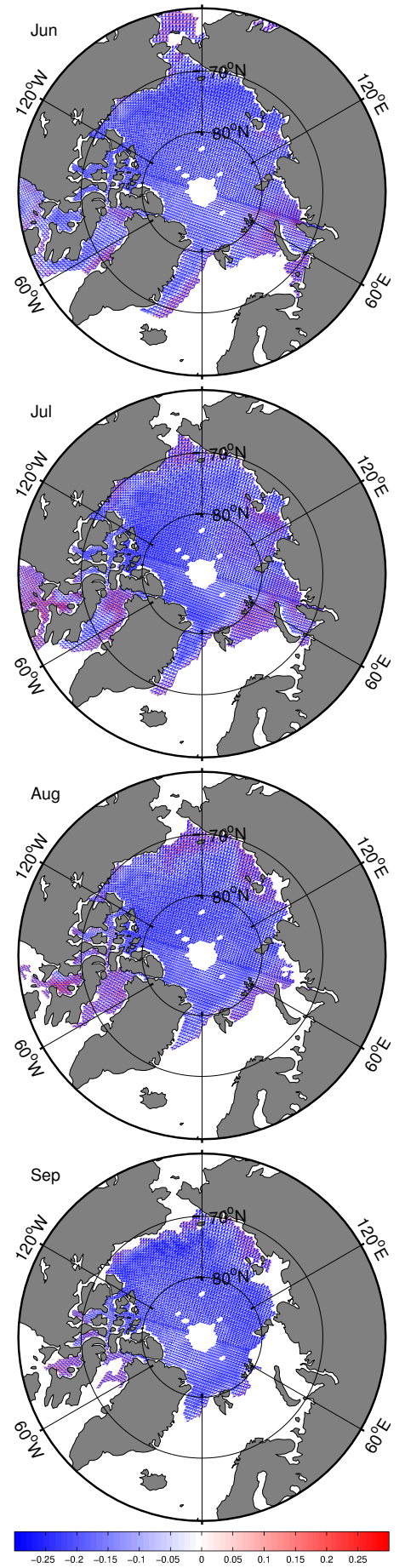

Figure 9: Average spatial distributions of the difference between modeled and observed pond fractions (of grid cell) over 2000-2011. 
However, this is to balance with the fact that IceBridge sensors may also have trouble discriminating the thinnest snow (Webster et al., 2014) classes. The shape of the SDDs, in Figure 12 especially, depict two maxima at 20-30 cm and 50-60 cm, while snow of moderate depth $(\sim 30 \mathrm{~cm})$ seems to be lacking.

425 Such bimodal SDDs are due to the ice type mixing in grid cells. First-year ice, represented by the thinnest ice thickness categories, is covered by relatively thin snow while older FYI or MYI (represented by intermediate and thick ice classes, respectively) carry thicker snow covers. Depending on the relative area coverage of each ice thickness category in grid cells, peaks associated to snow on each ice type appear more or less distinctly in the SDDs. This was observed in some individual data sets of the IceBridge product (Kurtz and Farrell, 2011, Kwok et al. 2011) and in other snow observation works (Gerland et al., 2014).

Although the average annual melt pond fraction cycle over 2000-2011 is in relatively good agreement with MODIS observations (Figure 7), its seems lower than in existing studies. In Flocco et al. (2012) (same melt pond scheme), their total and exposed melt pond fractions were reaching a maximum of 0.33 and 0.2 in average, against 0.28 and 0.15 in our control run. In the control simulation of Hunke et al. (2013) (different melt pond scheme), the maximum pond fraction of ice area was $\sim 0.4$ and the maximum pond fraction of a grid

${ }_{440}$ cell was 0.19 (against $\sim 0.15$ in our case). The reason for this underestimation of the mean annual cycle of pond fractions is the lack of melt ponds in the western Arctic Basin, as compared to both MODIS observations (see Figures 8 and 9 ) and those studies (especially Flocco et al. 2012). Apart from this shortcoming, melt ponds in CTL are are consistant with the latter studies, especially in terms of spatial variability. Both Flocco et al. (2012) and Hunke et al. (2013) had large melt pond fractions in July in the eastern basin (fractions of $\sim 0.3-0.35$ ) and in the Canadian Archipelago, like in CTL. The geographical distribution of melt pond depths in our control run (in July) is also very consistent with those of the two mentioned studies, with the deepest ponds $(0.3$ to $0.5 \mathrm{~m})$ along the north 450 coasts of Greenland and Canada. The regional variability of melt ponds in the simulation highlights patterns in opposition between pond depth and fractional coverage, particularly in the Central Arctic and the East Siberian Sea. This is characteristic of the melt pond scheme behavior. A shallow but spread out melt pond regime is observed on FYI, while concentrated and deeper melt ponds 455 form atop MYI with a pronounced topography (also confirmed by Figure 14). In addition, Flocco and Feltham (2007) showed that their model is very sensitive to the snow volume on top of sea ice, that can partially or even totally conceal the ponds. This provides the physical reason for the lack of melt ponds on the MYI of the western and central Arctic Basin in CTL, where some snow persists throughout the summer (Figure 11. 


\section{Sensitivity study : impacts of blowing snow on sea ice and melt ponds}

\subsection{Results}

In this section, we take advantage from having melt ponds and blowing snow both represented in our sea ice model to study the impacts of enhanced wind-transport of snow on melt pond distributions. So as to do this, CTL is compared to a second simulation called BSE (blowing snow enhanced simulation), in which the blowing snow tuning parameter $\gamma$ was increased to $10^{-4} \mathrm{~kg}$

$\mathrm{m}^{-2}$. Raising the value of this parameter practically increases the mass flux of snow removed from the pack when winds are strong enough for the snow drift process to occur. As mentioned previously, this parameter is underconstrained owing to lacking observations of wind-blown snow redistribution on sea ice, so the choice of its value for BSE was simply made keeping a compromise between getting noticeable differences in model outputs (BSE vs. CTL) and avoiding unrealistically strong transport rates. In part of the analysis, we distinguish the impacts on MYI from those on FYI.

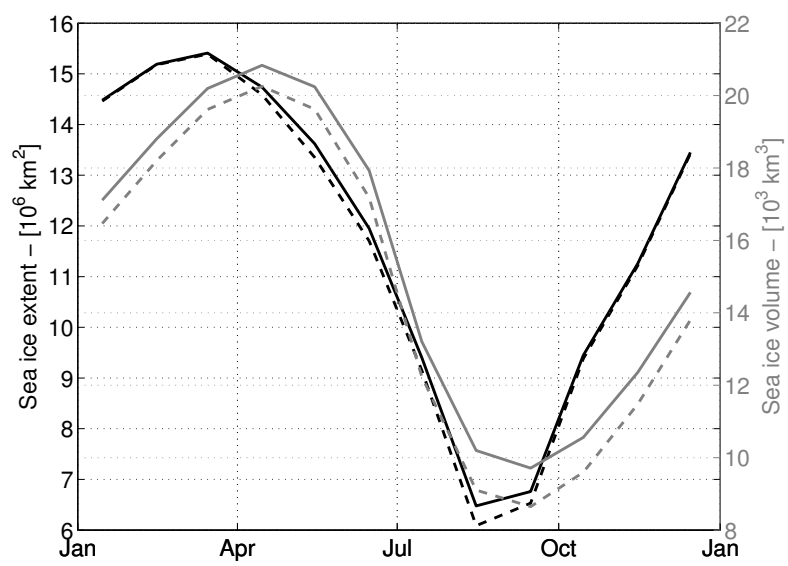

Figure 10: Mean annual cycles of sea ice extent (in black) and volume (grey) over 1982-2011 for CTL (solid lines) and BSE (dashed lines) simulations

\subsubsection{Impact on sea ice volume}

The mean annual cycles of sea ice extent and volume from BSE simulation, are compared to those from CTL in Figure 10. Only small differences are observed between the two cycles of sea ice extent, with a summer minimum slightly lower in BSE than CTL (6.1 against $\left.6.5 \times 10^{6} \mathrm{~km}^{2}\right)$. By contrast, the sea ice volume in BSE is systematically lower than in CTL throughout the year, with a winter maximum and a summer minimum decreased by 0.7 and $1.0 \times 10^{3}$ $\mathrm{km}^{3}$, respectively. In summer, the latter difference translates into a volume loss of about $10 \%$ with respect to CTL. Figure 11 shows that this volume loss 

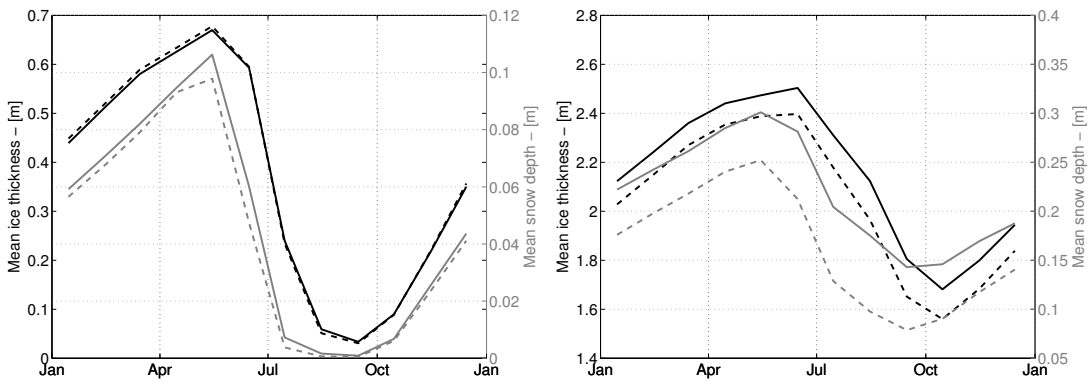

Figure 11: Mean annual cycles of ice thickness (black) and snow depth (grey) for CTL (solid) and BSE (dashed), computed over FYI (left) and MYI (right), through 1982-2011.

is exclusively experienced by MYI, with a 10-15 cm lower mean ice thickness in BSE, while the annual cycle of FYI thickness is almost identical in both simulations.

\subsubsection{Snow depth changes}

As illustrated by Figures 11 and 12 , the primary effect of enhanced windtransport of snow in the model is to reduce the snow depth on sea ice by removing it from the pack and transferring it into leads during the redistribution process. Therefore, the MYI snow depth distributions of BSE (in May, at the onset of melt pond formation) are clearly shifted towards thinner snow. In BSE, snow deeper than $70 \mathrm{~cm}$, that represents $\sim 13 \%$ of the snow pack in CTL, has virtually disappeared, whereas the proportion of $0-20 \mathrm{~cm}$ deep snow has increased by $10 \%$. This snow thinning effect is much less noticeable on FYI. An explicit bimodal SDD is again observable on MYI in both simulations, with peaks at 10 and $55 \mathrm{~cm}$ of snow that are all the more distinct in case of stronger erosion (BSE).
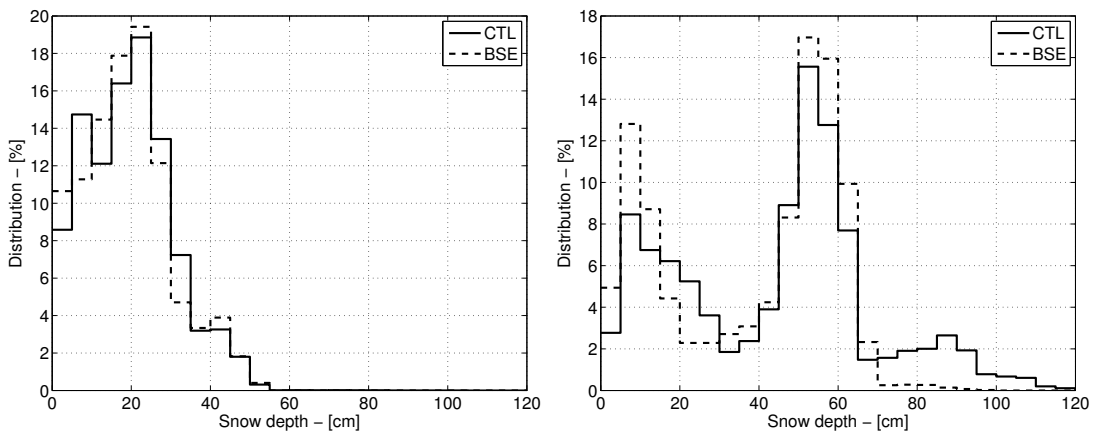

Figure 12: May snow depth distributions for CTL (solid lines) and BSE (dashed lines), averaged over the FYI (left) and MYI (right) area, over 1982-2011. 


\subsubsection{Impacts on melt pond distributions}

The SDDs at the onset of the melting season impact on the melt pond development in the simulations. Figure 13 shows that the main effect of the overall reduced snow depths on Arctic sea ice is a small increase in average melt pond fraction $(\sim 3 \%)$ and depth $(2.5 \mathrm{~cm})$. Nonetheless, those global diagnostics hide interesting changes on MYI, as suggested by Figure 14, which depicts the changes in melt pond fractional coverage and depth between CTL and BSE for each ice type (i.e., FYI and MYI). The maximum melt pond area and depth on FYI seems to decrease in BSE, as compared to CTL, but those differences are very small $(-1 \%$ and $-0.5 \mathrm{~cm}$, respectively). In contrast, the MYI melt pond cover in BSE exhibits a faster development, which leads to more considerable changes in both fractional coverage $(+5 \%$ coverage $)$ and depth $(+\sim 4 \mathrm{~cm})$. The observed magnitude of the changes in melt pond distribution between the two simulations are consistent with those in SDD. Interestingly, although the changes on FYI are weak, they suggest a melt pond regime that differs from the one on MYI, with a melt pond volume seemingly decreasing in BSE (further discussed in section 6.2.

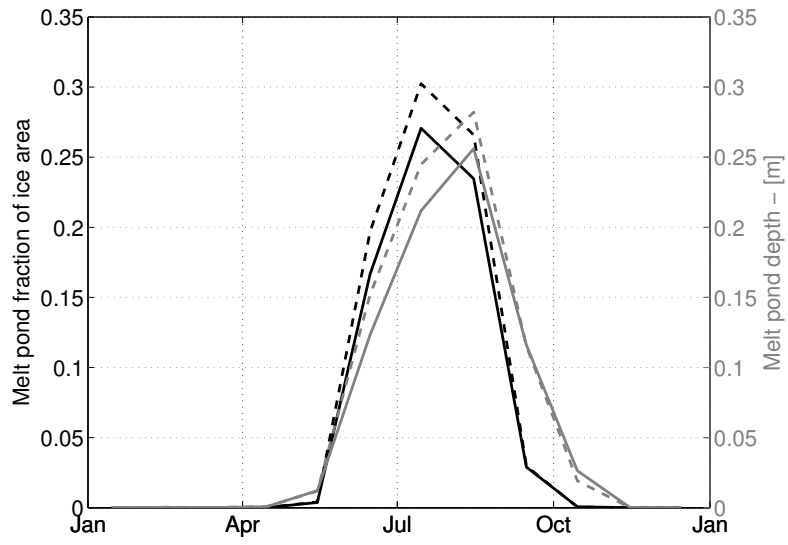

Figure 13: 1982-2011 mean seasonal cycles of melt pond fraction (black) and depth (grey) for CTL (solid lines) and BSE (dashed lines) simulations.

\subsection{Discussion}

Figures 13 and 14 suggest that, on average over the whole pond-covered ice and on MYI specifically, increased snow drift leads to increased pond volume. On the other hand, the FYI melt pond cover seems to respond differently. The first physical reason for these differences in response lies in the primary effect of the blowing snow process in the model: sending a fraction of the sea ice snow cover into leads. The second mechanism, altering the shape of snow depth distributions, is unexpectedly hardly effective in this case. This may be due to inadequate criteria for snow redistribution among ice thickness categories 

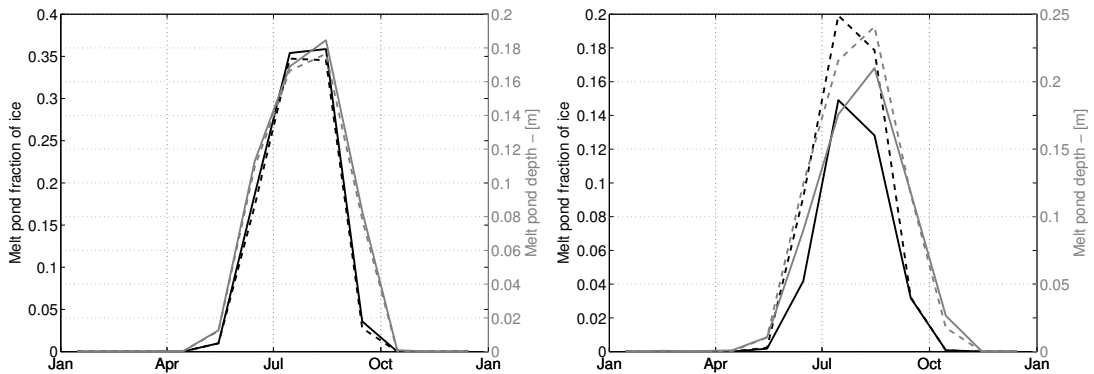

Figure 14: 1982-2011 mean seasonal cycles of melt pond fraction (black) and depth (grey) for CTL (solid lines) and BSE (dashed lines) simulations, and for each ice type (FYI on the left; MYI on the right).

and stresses the need for future improvements of this parameterization. The resulting snow thinning is illustrated in Figures 11 and 12 . In the simulations, snow does not entirely melt away in MYI regions and the blowing snow process influences the snow depth distributions both during winter and after the onset of the melt season. Note that this may not be realistic since snow melts completely in summer at the North Pole buoys sites (Perovich et al., 2014). In case of a greater wind-transport of snow, such as in BSE, less snow is available on sea ice to hide melt ponds and impede their development (as shown in Figure 14). The overall increased melt pond fraction in this simulation in turn results in increased ice melt through the ice-albedo feedback and explains the lower MYI volume, as compared to CTL (see Figures 10 and 11, right panel).

The latter mechanism was not necessarily to be expected since, for instance, the opposite consequence was observed in Flocco et al. (2012) in which a simulation with increased precipitation led to more snow available to melt and feed the ponds. Nonetheless, those two behaviors are not inconsistent and are due to the specific influence of our blowing snow parameterization on FYI and MYI. Less (more) snow leading to smaller (larger) melt pond area is to be expected when the total snow cover is melted whatever its depth, which is the case on FYI of both simulations (see Figure 11). FYI however, once it starts forming, quickly reaches high concentrations and covers most of a model grid cell, meaning that when snow is blown by winds, little is lost into the ocean and most of it is redeposited on the ice it was removed from. Figure 12 left panel clearly underlines the reduced effect of blowing snow redistribution on FYI. Eventually, 550 when the open water fraction is large enough in summer to capture snow, most of it is already melted and filling in melt ponds. In addition, independently of the snow cover on flat FYI, the liquid meltwater volume transportable on such ice is naturally limited by its topography. As a consequence, FYI in the model might naturally tend to fill with meltwater at full capacity anyway and be less sensitive to the overlying snow volume prior to the onset of the melting season. Thus, strengthened snow drift has little influence on melt pond formation on FYI (Figure 14), which also explains the rather weak impact at the basin scale (Figure 13). 


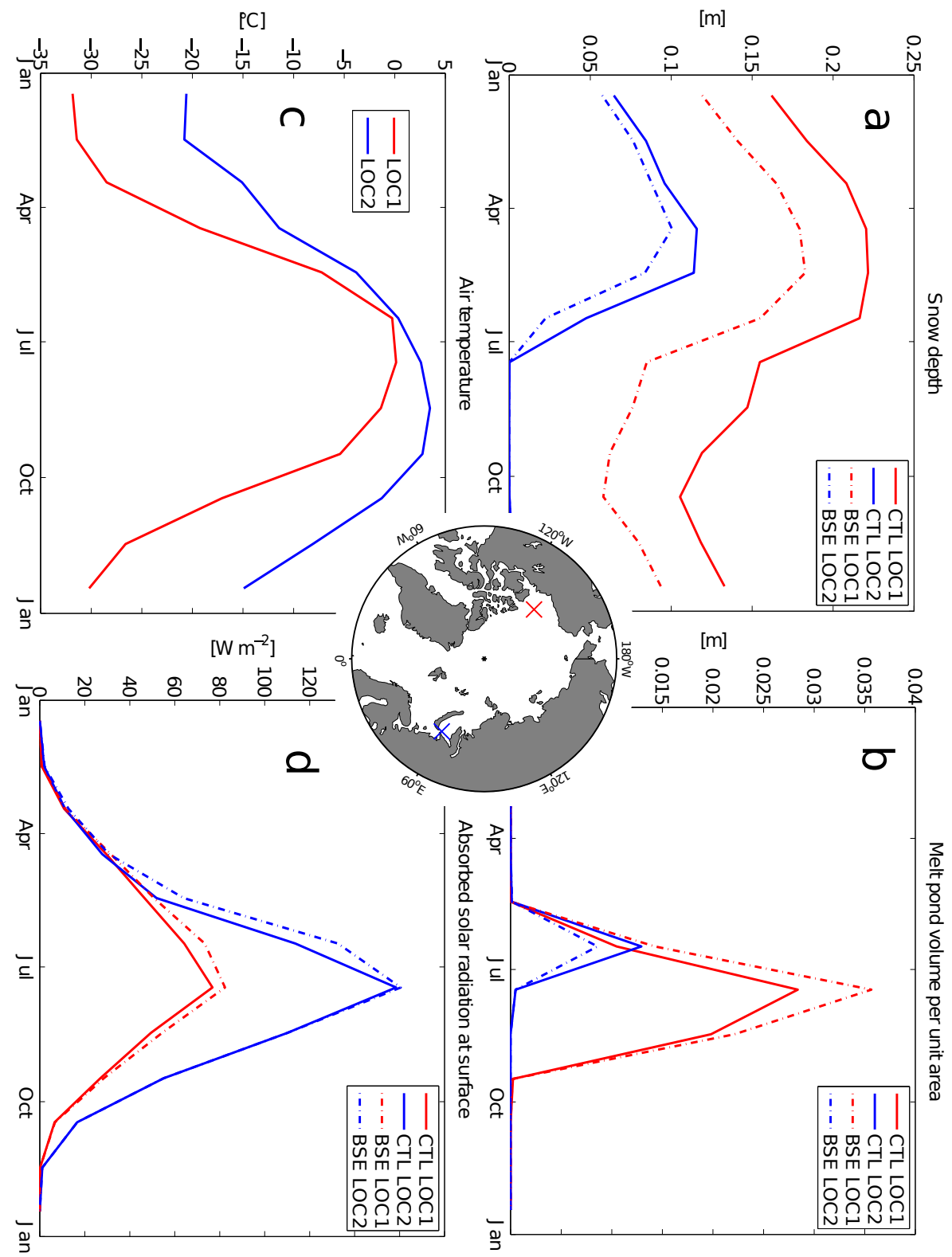

Figure 15: 1982-2011 climatologies of (a) snow depth, (b) melt pond volume, (c) air temperature and (d) absorbed solar radiation at the snow/ice surface, at two locations of the Arctic Basin. Those locations are shown on the central map. The first (LOC1, in red) is on MYI, and the second (LOC2, in blue) on FYI. Solid and dashed lines depict the climatologies for CTL and BSE simulations, respectively. 
Figure 14 (left panel) does not only suggest a reduced sensitivity of FYI

\section{Conclusion}

In order to study the influence of the sea ice late-spring snow cover on the development of melt ponds and the large-scale implications for sea ice, the ex600 plicit melt pond model of Flocco and Feltham (2007) was incorporated into a coupled ocean-sea ice model including an advanced snow representation and a blowing snow parameterization. The comparison of a control simulation with 
MODIS satellite observations over the 2000-2011 period demonstrates a relatively good model ability to reproduce the spatial variability of melt pond depth and a proper mean annual cycle of melt pond fraction on average over the Arctic Basin. However, even keeping in mind the degree of uncertainty of MODIS melt pond fractions, the model seems to fail in simulating satisfactory pond fractions on MYI, where the concealing effect of persistent snow curtails the horizontal development of melt ponds. This results in an underestimation ${ }_{610}$ of pond fraction by up to 0.2 in the western basin, along the northern coasts of Greenland and Canada, while flat FYI regions of the peripheral basin are sometimes over-covered by ponds. A difference in maximum of the mean melt pond fraction of about 5 to $10 \%$ toward smaller pond area is observed compared to Flocco et al. (2012) and Hunke et al. (2013). As in those studies, the sea ice volume in our control run compared to a no-pond configuration (Lecomte et al. 2013) is much lower (up to $50 \%$ volume loss) due to the ice-albedo feedback. Consistently, the simulated late-spring ITD compared to the IceBridge dataset exhibits an excessive proportion of $0.7-2.3 \mathrm{~m}$ thick ice, while it lacks ice in the thickest two categories of the model $(2.3-5.5 \mathrm{~m})$. The comparison ${ }_{620}$ of corresponding SDDs versus IceBridge observations therefore shows a slight bias toward thinner snow as well, which is characterized by an overestimation of very thin snow $(0-5 \mathrm{~cm})$. In spite of this, the tail of the SDDs remains in good agreement with observations.

The main effect of the blowing snow parameterization is to reduce snow depth on sea ice by sending a fraction of the transported snow into the leads. Increasing the intensity of snow redistribution by winds therefore subserves further snow thinning in the associated simulation. Quite surprisingly, the snow drift intensity does not change the shape of the simulated snow depth distributions much, which may be due to inadequate erosion or redistribution criteria in the blowing snow scheme. From there, two melt pond regimes and causal relationships are clearly identified. On MYI, where some snow persists through the summer, the smaller snow volume ensuing from enhanced snow drift has a weaker concealing effect on melt ponds, and facilitates their development. In an other situation, apparently more typical of FYI, a combined effect of higher ${ }_{635}$ air temperatures and relatively thin snow makes it a snow cover that entirely melts in summer. Hence, less snow leads to faster sea ice thinning and smaller pond fractions since the amount of freshwater potentially retained at the surface, already limited on FYI, is decreased. The magnitude of such changes is thus smaller than those observed on MYI. The enhanced melt pond formation on MYI in case of increased wind-blown snow redistribution is thus substantially lessened if observed in average over the whole Arctic sea ice cover. Even so, it is influential enough to cause a $10 \%$ summer ice volume loss, with regard to our control simulation. It should finally be stated that our results might be influenced by the number of ice thickness categories in the model given poten-

${ }_{645}$ tial sensitivity of both our blowing snow parameterization and the melt pond scheme (Flocco and Feltham, 2007, Flocco et al., 2010) to that parameter.

Ultimately, the particular behavior of the blowing snow parameterization and the specific melt pond regimes on FYI as opposed to MYI raises two issues 
still needing to be addressed. The first concerns the respective sensitivity of FYI and MYI to snow-related processes and properties in sea ice models, in general. Going further, the second regards the actual benefits of including detailed snow parameterizations into sea ice - ocean models running under current climate conditions, i.e., sustaining a progressive transition of sea ice towards a FYI exclusive cover.

Cheng, B., Vihma, T., Pirazzini, R., Granskog, M., 2006. Modelling of superimposed ice formation during the spring snowmelt period in the Baltic Sea. Annals of Glaciology 44, 139-146.

Comiso, J., Nishio, F., 2008. Trends in the sea ice cover using enhanced and compatible AMSR-E, SSM/I, and SMMR data. Journal of Geophysical Research 113, C02S07.

Dai, A., Trenberth, K., 2002. Estimates of freshwater discharge from continents: Latitudinal and seasonal variations. Journal of Hydrometeorology 3, 660-687. 
Dee, D., Uppala, S., Simmons, A., Berrisford, P., Poli, P., Kobayashi, S., Andrae, U., Balmaseda, M., Balsamo, G., Bauer, P., et al., 2011. The ERAInterim reanalysis: Configuration and performance of the data assimilation system. Quarterly Journal of the Royal Meteorological Society 137, 553-597.

Déry, S., Tremblay, L., 2004. Modeling the Effects of Wind Redistribution on the Snow Mass Budget of Polar Sea Ice*. Journal of Physical Oceanography $34,258-271$.

Déry, S., Yau, M., 2002. Large-scale mass balance effects of blowing snow and surface sublimation. Journal of Geophysical Research-Atmospheres 107, ACL-8.

Dussin, R., Barnier, B., 2013. The Making of DFS 5.1. personnal communication, http://www.drakkar-ocean.eu/forcing-the-ocean .

Eicken, H., Grenfell, T., Perovich, D., Richter-Menge, J., Frey, K., 2004. Hydraulic controls of summer Arctic pack ice albedo. Journal of Geophysical Research-Oceans 109.

Feltham, D., Untersteiner, N., Wettlaufer, J., Worster, M., 2006. Sea ice is a mushy layer. Geophysical research letters 33 .

Fetterer, F., Untersteiner, N., 1998. Observations of melt ponds on Arctic sea ice. Journal of Geophysical Research-Oceans 103, 24821-24835.

Fichefet, T., Morales Maqueda, M., 1997. Sensitivity of a global sea ice model to the treatment of ice thermodynamics and dynamics. Journal of Geophysical Research-Oceans 102.

Flocco, D., Feltham, D., 2007. A continuum model of melt pond evolution on Arctic sea ice. Journal of Geophysical Research 112, C08016.

Flocco, D., Feltham, D., Turner, A., 2010. Incorporation of a physically based melt pond scheme into the sea ice component of a climate model. Journal of Geophysical Research 115, C08012.

Flocco, D., Schroeder, D., Feltham, D., Hunke, E., 2012. Impact of melt ponds on Arctic sea ice simulations from 1990 to 2007. Journal of Geophysical Research-Oceans 117.

Freitag, J., Eicken, H., 2003. Meltwater circulation and permeability of Arctic summer sea ice derived from hydrological field experiments. Journal of glaciology 49, 349-358.

Gerland, S., Haas, C., Wang, C., Granskog, M., Haapala, J., Makshtas, A., 2014. Snow thickness distributions over sea ice in the vicinity of the North Pole, 2005-13, Abstract presented at 2014 IGS International Symposium on Sea Ice in a Changing Environment, Hobart, Tas., 10-14 Mar. 69A668. . 
Girard, L., Bouillon, S., Weiss, J., Amitrano, D., Fichefet, T., Legat, V., 2011. A new modeling framework for sea-ice mechanics based on elasto-brittle rheology. Annals of Glaciology 52, 123-132.

Golden, K., Eicken, H., Heaton, A., Miner, J., Pringle, D., Zhu, J., 2007. Thermal evolution of permeability and microstructure in sea ice. Geophysical Research Letters 34.

Goosse, H., 1997. Modeling the large-scale behavior of the coupled ocean-sea ice system. Ph.D. thesis, 231 pp., Univ. Catholique de Louvain, Louvain-laNeuve, Belgium. .

730 Goosse, H., Fichefet, T., 1999. Importance of ice-ocean interactions for the global ocean circulation: A model study. Journal of Geophysical Research 104, 23337-23355.

Holland, M., Bailey, D., Briegleb, B., Light, B., Hunke, E., 2012. Improved sea ice shortwave radiation physics in CCSM4: the impact of melt ponds and aerosols on Arctic sea ice. Journal of Climate 25, 1413-1430.

Holland, M., Bitz, C., Hunke, E., Lipscomb, W., Schramm, J., 2006. Influence of the sea ice thickness distribution on polar climate in CCSM3. Journal of Climate 19, 2398-2414.

Hunke, E., Dukowicz, J., 1997. An elastic-viscous-plastic model for sea ice dynamics. Journal of Physical Oceanography 27, 1849-1867.

Hunke, E., Hebert, D., Lecomte, O., 2013. Level-ice melt ponds in the Los Alamos sea ice model, \{CICE\}. Ocean Modelling 71,

26-42. URL: http://www.sciencedirect.com/science/article/pii/ S1463500312001680 doi $10.1016 /$ j.ocemod.2012.11.008.

ICDC MODIS, 2013. Arctic melt pond cover fractions were obtained for 2000-2011 from the Integrated Climate Data Center (ICDC, http://icdc.zmaw,de/), University of Hamburg, Hamburg, Germany, September 2013 .

Järvinen, O., Lepparanta, M., 2011. Transmission of solar radiation through the snow cover on floating ice. Journal of Glaciology 57, 861-870.

Jordan, R., Albert, M., Brun, E., 2008. Physical processes within the snow cover and their parameterization, in Snow and Climate: Physical Processes, Surface Energy Exchange and Modeling, by Armstrong, R. and Brun, E., Cambridge University Press, 12-69.

Kalnay, E., Kanamitsu, M., Kistler, R., Collins, W., Deaven, D., Gandin, L., Iredell, M., Sana, S., White, G., Woollen, J., et al., 1996. The NCEP/NCAR 40-Year Reanalysis Project. Bulletin-American Meteorological Society 77, $437-471$. 
King, J., Pomeroy, J., Gray, D., Fierz, C., Föhn, P., Harding, R., Jordan, R., Martin, E., Plüss, C., 2008. Snow-Atmosphere energy and mass balance, in Snow and Climate: Physical Processes, Surface Energy Exchange and Modeling, by Armstrong, R. and Brun, E., Cambridge University Press , 70-124.

Kurtz, N., Farrell, S., 2011. Large-scale surveys of snow depth on Arctic sea ice from Operation IceBridge. Geophysical Research Letters 38, L20505.

765 Kurtz, N., Studinger, M.S., Harbeck, J., Onana, V., Farrell, S., 2012, updated 2013. IceBridge Sea Ice Freeboard, Snow Depth, and Thickness. Boulder, Colorado USA: NASA DAAC at the National Snow and Ice Data Center. http://nsidc.org/data/idcsi2.html .

Kwok, R., Panzer, B., Leuschen, C., Pang, S., Markus, T., Holt, B., Gogineni, S., 2011. Airborne surveys of snow depth over Arctic sea ice. Journal of Geophysical Research 116, C11018.

Large, W., Yeager, S., 2004. Diurnal to decadal global forcing for ocean and seaice models: The data sets and flux climatologies. NCAR Tech. Note TN-460+ STR .

775 Lecomte, O., Fichefet, T., Vancoppenolle, M., Domine, F., Massonnet, F., Mathiot, P., Morin, S., Barriat, P., 2013. On the formulation of snow thermal conductivity in large-scale sea ice models. Journal of Advances in Modeling Earth Systems 5, 542-557. URL: http://dx.doi.org/10.1002/jame.20039, doi:10.1002/jame.20039.

Lecomte, O., Fichefet, T., Vancoppenolle, M., Nicolaus, M., 2011. A new snow thermodynamic scheme for large-scale sea-ice models. Annals of Glaciology $52,337-346$.

Leonard, K., Maksym, T., 2011. The importance of wind-blown snow redistribution to snow accumulation on Bellingshausen Sea ice. Annals of Glaciology $52,271-278$.

Levitus, S., 1998. NODC World Ocean Atlas, http://www.esrl.noaa.gov/psd/ .

Madec, G., 2008. NEMO ocean engine: Note du Pole de Modelisation, Instin tut Pierre-Simon Laplace URL: http://www.nemo-ocean.eu/About-NEMO/ Reference-manuals.

Pedersen, C., Roeckner, E., Lüthje, M., Winther, J., 2009. A new sea ice albedo scheme including melt ponds for ECHAM5 general circulation model. Journal of Geophysical Research-Atmospheres 114.

Perovich, D., Grenfell, T., Light, B., Hobbs, P., 2002. Seasonal evolution of the albedo of multiyear Arctic sea ice. Journal of Geophysical Research-Oceans 107, SHE-20. 
Perovich, D., Richter-Menge, J., Polashenski, C., Elder, B., Arbetter, T., Brennick, O., 2014. Sea ice mass balance observations from the North Pole Environmental Observatory. Geophysical Research Letters 41, 2019-2025. URL: http://dx.doi.org/10.1002/2014GL059356, doi:10.1002/2014GL059356.

Petrich, C., Eicken, H., Polashenski, C., Sturm, M., Harbeck, J., Perovich, D., Finnegan, D., 2012. Snow dunes: A controlling factor of melt pond distribution on Arctic sea ice. Journal of Geophysical Research-Oceans 117.

Polashenski, C., Perovich, D., Courville, Z., 2012. The mechanisms of sea ice melt pond formation and evolution. Journal of Geophysical Research-Oceans 117.

Rösel, A., Kaleschke, L., Birnbaum, G., 2012. Melt ponds on Arctic sea ice determined from MODIS satellite data using an artificial neural network. The Cryosphere 6, 431-446.

Shine, K., Henderson-Sellers, A., 1985. The sensitivity of a thermodynamic sea ice model to changes in surface albedo parameterization. Journal of Geophysical Research-Atmospheres 90, 2243-2250.

Simmons, A., Uppala, S., Dee, D., Kobayashi, S., 2007. ERA-Interim: New ECMWF reanalysis products from 1989 onwards. ECMWF newsletter 110, $25-35$.

Sturm, M., Holmgren, J., Perovich, D., 2002. Winter snow cover on the sea ice of the Arctic Ocean at the Surface Heat Budget of the Arctic Ocean (SHEBA): Temporal evolution and spatial variability. Journal of Geophysical Research 107.

Sturm, M., Massom, R., 2009. Snow and Sea Ice, in Sea ice, 2nd Ed., by Thomas, D.N. and Dieckmann, G., Wiley-Blackwell , Chapter 5, 153-204.

Sugiura, K., Nishimura, K., Maeno, N., Kimura, T., 1998. Measurements of snow mass flux and transport rate at different particle diameters in drifting snow. Cold Regions Science and Technology 27, 83-89.

Trenberth, K., Large, W., European Center for Medium Range Weather Forecasts, 1989. A global ocean wind stress climatology based on the ECMWF analyses. URL: http://dss.ucar.edu/datasets/ds110.1/.

Vancoppenolle, M., Fichefet, T., Goosse, H., Bouillon, S., Madec, G., Maqueda, M., 2009. Simulating the mass balance and salinity of Arctic and Antarctic sea ice. 1. Model description and validation. Ocean Modelling 27, 33-53.

830

Webster, M., Rigor, I., Nghiem, S., Kurtz, N., Farrell, S., Perovich, D., Sturm, M., 2014. Interdecadal changes in snow depth on Arctic sea ice. Journal of Geophysical Research-Oceans . 
Zhang, J., Rothrock, D., 2003. Modeling global sea ice with a thickness and enthalpy distribution model in generalized curvilinear coordinates. Monthly Weather Review 131, 845-861. 